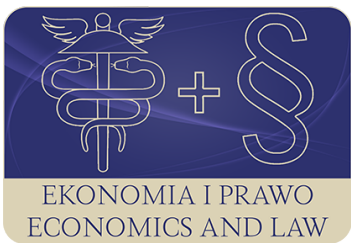

EKONOMIA I PRAWO. ECONOMICS AND LAW

Volume 15, Issue 3, September 2016

p-ISSN 1898-2255, e-ISSN 2392-1625

www.economicsandlaw.pl

ORIGINAL ARTICLE

received 22.11.2016; revised 24.01.2007; accepted 24.01.2017

Citation: Krupa, D. \& Buszko, M. (2016). Characteristics and prospects of development

of securitisation investment funds market in Poland. Ekonomia i Prawo. Ecomomics and Law, 15(3): 357-370. doi:10.12775/EiP.2016.024.

\title{
Characteristics and prospects of development of securitisation investment funds market in Poland
}

\author{
DOROTA KRUPA \\ corresponding author \\ Nicolaus Copernicus University, Faculty of Economic Science and Management, Department \\ of Finance, ul. Gagarina 13A, 87-100 Toruń, Poland \\ 口dkrupa@umk.pl \\ MICHAE BUSZKO \\ Nicolaus Copernicus University, Faculty of Economic Science and Management, Department \\ of Finance, Poland \\ వmibus@umk.pl
}

\begin{abstract}
Motivation: Securitisation investment funds are considered as the most suitable vehicle for the process of securitisation. The paper refers to the issue of establishing, functioning and development of securitisation investment funds in Poland, which are special type

of closed-end investment funds managed by investment fund companies (IFC).

Aim: The aim of the paper is an appraisal of the securitisation investment funds market in Poland with a special attention paid to its evolution and prospects of development. In the paper a securitisation investment fund was presented as a one of the type of investment funds in Poland based on the Polish legislation. We enclose the results of the survey conducted in Poland amongst the mentioned funds and present the appraisal of major stimulants and barriers of development of securitisation and securitisation investment funds market.

Results: Upon the research we find that despite low level of using of securitisation in the past its perspectives of development are appraised positively by IFCs. Majority of questioned IFCs indicate existence of particular barriers for development of securitisation in Poland. According to IFCs with and without securitisation investment funds, the most problematic areas are: lack of proper regulations and high complexity of the se-
\end{abstract}


curitisation itself. From the point of view of investment funds industry securitisation is evaluated as of average interest despite funds are leading in development of the considered financial technique in Poland.

Keywords: securitisation; securitisation fund; investment fund; alternative investment fund; investment fund company

JEL: G17, G23, G28

\section{Introduction}

The paper refers to the issue of establishing, functioning and development of securitisation investment funds in Poland, which are alternative investment funds managed by investment fund companies (IFC). The main goals of the paper are: characteristics of functioning of securitisation investment funds market in Poland, evaluation of perspectives as well as identification of factors and barriers of its development.

A securitisation investment fund was presented as a one of the type of investment funds in Poland based on the Polish legislation. To achieve the goals were carried out two types of researches. The fist research involved analysis of the securitisation funds market in Poland, together with an indication of their role in the whole investment fund market in Poland. It takes into account the state of data in May 2016. We based our work on data obtained from The Chamber of Fund and Asset Management and Polish Financial Supervision Authority. The paper also contains selected results of the survey research on securitisation funds conducted in 2015, whose aim was to obtain information on functioning and development of securitisation funds in Poland. Some part of results of the survey research was already presented and it contained the chosen aspects of functioning of securitisation funds from the perspective of such investment fund companies (IFC), which had in his offer securitisation funds (Krupa \& Buszko, 2015, pp. 379-387).

The idea of functioning of securitisation funds as the vehicles combining processes of securitisation, where they are used as special purpose vehicles (SPV), with the structure of investment fund was presented in the first article of the series titled Discussion about developing securitisation in Poland with participation of securitisation investment funds. In the mentioned article, factors determining as well as limiting development of securitisation in Poland with participation of securitisation investment funds functioning as SPVs were identified and discussed. The paper also presented detailed legal aspects of conducting securitisation in Poland with the participation of securitisation investment funds. 


\section{Securitisation investment funds as a type of investment fund in Poland}

The Polish investment funds market exists for almost 25 years. Nowadays, it operates upon the Act of May 27, 2004, which was amendment in 2016 taking into account EU directives: UCITS V and AIFM (Investment Funds and Management of Alternative Investment Funds Act, 2004). According to Polish law three main types of investment funds are allowed in Poland:

- open-end investment funds,

- specialized open-end investment funds,

- closed-end investment funds.

In Poland, only the investment fund company (IFC) can create and manage an investment fund (Krupa, 2008). At the end of May 2016 the Polish Financial Supervision Authority licensed sixty-one Investment Fund Companies. Thirty-nine IFCs reported financial data to The Chamber of Fund and Asset Management.

Open-end funds are harmonized investment funds at EU level. This type of fund is called UCITS funds (undertakings for the collective investment in transferable securities). The acronym 'UCITS' refers to a series of EU directives that have established a uniform regulatory regime for the creation, management and marketing of collective investment vehicles in the EU countries. The first UCITS Directive was adopted on December 20, 1985 (Directive $85 / 611 / \mathrm{EEC}$ ). The aim of this directive was facilitating cross-border offering of investment funds to retail investors. In 2002 Directives 2001/107/EC (2002) and 2001/108/EC (2002) were adopted, together known as UCITS III. Generally UCITS III broadened the investment spectrum of UCITS funds. UCITS IV (Directive 2009/65/EC) was the next directive, which brought additional technical changes and was adopted in July 2011. UCITS V (Directive 2014/91/EU) went into force in March 2016. Its aim was aligning fund depositories' duties and responsibilities and fund managers' remuneration requirements.

The other two types of investment funds in Poland (specialized open-end investment funds and closed-end investment funds) are recognised as alternative investment funds. The rules of management alternative investment fund in Poland were adapted to the Alternative Investment Fund Managers Directive (AIFMD Directive 2011/61/EU) in 2016 in Investment Funds and Management of Alternative Investment Funds Act, how was mentioned earlier.

The closed-end investment fund is one of the most flexible types of investment funds in Poland. This type can be used to establish investment funds with lower investment restrictions as compared to the open-end investment funds, which must operate on the basis of very rigid regulations. A closed-end investment fund may be created as a securitisation fund which issues investment certificates in order to accumulate funds for the acquisition of receivables (debts), including receivables financed with public funds, as defined in separate regulations, and/or for the rights to income from specific receivables (Act 
on investment funds and management of alternative investment funds, 2004). A securitisation fund can be created in a standardised or non-standardised form. The idea of the participation of the securitisation fund in the process of securitisation was described in the first article of the series. In Poland, the securitisation investment funds are considered as the most convenient intermediary in the securitisation processes (Liskowska, 2006, p. 25). They are used either in securitisation of bank or non-bank assets. As in Poland there is no single act on securitisation, the process itself is conducted based on various acts, including Banking Law (1997), Act on investment funds and management of alternative investment funds (2004), Act on bonds (2015) and other acts.

\section{The methodology of research and research process}

To achieve the main purpose of the paper, which was an appraisal of the securitisation investment funds market in Poland with a special attention paid to its evolution and prospects of development, two researches was undertaken.

The fist research involved analysis of the securitisation funds market in Poland, together with an indication of their role in the whole investment fund market in Poland. It takes into account the state of data in May 2016.

The base for the second research is selected results of the original survey research prepared and conducted by the authors of this paper. The research took place in period March-April 2015 in Poland and included all investment fund companies in Poland. The title of the research was 'Securitisation funds in Poland - functioning and development'. The research was a further step of works conducted by the authors in Nicolaus Copernicus University in scope of closed-end investment funds and transactions of securitisation. The research was supported by the Students' Science Club in Banking at Nicholas Copernicus University. The survey of the research consisted of a website questionnaire which was available through the webpage link sent by email to all 56 investment fund companies (table 1.).

Totally 14 questionnaires were sent back from IFCs, which managed thirty-eight of the seventy securitisation investment funds operated in Poland in period of the research. Some part of the results of the research in scope of management of securitisation funds was already presented (Krupa \& Buszko, 2015, pp. 379-387).

\section{The results of research}

\subsection{The securitisation funds market in Poland}

Net asset value (NAV) of the investment funds market in Poland as on the end of May 2016 reached PLN 260bn (nearly EUR 50bn) what constitutes about $0.5 \%$ of NAV of the European investment funds market. Open-end investment 
funds concentrate $35 \%$ share in NAV of the Polish investment fund market, specialised open-end funds and closed-end funds, accordingly $15 \%$ and $47 \%$ of NAV at the end of May 2016. A securitisation investment fund, in accordance with Polish law, is one of the types of closed-end investment funds. Chart 1 presents the structure of the NAV of investment funds market in Poland. The share of securitisation funds in the total number of funds is 6\% (chart 2).

The securitisation funds market in Poland has been existing for more than ten years. At the end of May 2016 there were registered 97 securitisation funds in Poland offered by twenty-five IFCs ${ }^{1}$. NAV of this group of securitisation funds was PLN 5.653bn (approximately EUR 1.294bn). The share of securitisation funds in the NAV of investment funds market in Poland, is only 2\% (chart 1), the share of securitisation funds in the total number of funds is about $6 \%$ (chart 2). In spite of such a low share of securitisation funds in the investment funds market and lack of full data about this market one can see that the development of this segment of the fund market is intense (chart 3).

Chart 3 shows that IFC steadily increase the volume of securitisation funds and their NAV by creating funds directed to various groups of investors. Investment certificates of securitisation funds allow them to diversify their investment portfolios, to structure individual risk profiles and to invest the money in debt collection services. Non-dedicated funds may become popular in the future but nowadays the dominant role is played by dedicated funds. Chart 4 . presents the rank of IFCs with the biggest NAV of securitisation funds in period 2012-2016.

\subsection{The perspectives of development of securitisation investment funds according to IFCs}

Considering the perspectives of development of assets securitisation in Poland in the next few years. Most of the IFCs indicated rather good perspectives (most commonly grade 4 in the $0-5$ grade rank). The IFCs managing securitisation funds indicated as a rule better perspectives comparing to the IFCs without securitisation funds (chart 5). None of the IFC indicated the best perspectives (grade 5). Also none of them indicated lack of perspectives (grade 0). The average grade of the IFCs with securitisation funds was 3.625 while from IFCs without securitisation funds 3.0. Such result confirms better perspectives of development of the securitisation by the entities dealing with this technique and having professional experience in such field of finance.

The IFCs having securitisation funds in their portfolio more often pointed out the limitations and barriers for the process of development of the securitisation than IFCs without securitisation funds (table 2).

When analysing types of barriers and limitations of development of securitisation in Poland one can find rather similar indications of IFCs which manage

${ }^{1}$ Fourteen of these IFCs are reporting data to The Chamber of Fund and Asset Management. 
securitisation funds and the IFCs without securitisation funds under management (chart 6). The IFCs with securitisation funds indicated that three main limitations hindering development of securitisation (according to total importance) are: lack of proper legal regulations (total score 5), high complexity of transaction process (3) and problems with taxation (3). The IFCs without securitisation funds indicated top 3 limitations as: high costs of securitisation (total score 7), high complexity of the process (7) and lack of proper legal regulations (6). In both groups common problem areas are: lack of proper regulations and high complexity of the securitisation itself. The IFCs non-managing securitisation funds indicate also high costs of transactions, what is not a particular problem in opinion of IFCs with securitisation funds. Such difference of indications may be a result of experience in managing the securitisation processes by IFC with securitisation funds. Both groups also mentioned problems with taxation as a limitation for securitisation development, however the IFCs without securitisation funds indicated it on the fourth place altogether with the limitation of lack of proper assets for securitisation (total score 5).

The IFCs participated in the research were asked about potential of future importance of securitisation for IFCs in Poland (chart 7). Both groups of IFCs, i.e. those managing securitisation funds and IFCs without securitisation funds answered similarly and most often indicated an average importance of securitisation for investment funds industry. Moreover, two of the IFCs managing securitisation funds declared that securitisation would have marginal importance for investment funds companies. The explanation of such answers may be a high speciality of the securitisation itself and a high competitiveness of traditional assets for IFCs.

IFCs were also asked about types of securitisation funds, which are expected to be established in Poland in the next few years (chart 8). The two groups of IFCs, i.e. having and not having securitisation funds in the portfolio, pointed different types. The IFCs managing securitisation funds choose non-standardised dedicated funds as potentially most commonly established (6 indications). The non-securitisation funds IFCs indicated both non-standardised non-dedicated (3) and non-standardised dedicated (2). None of the IFCs claimed that the standardised funds would be most commonly established in Poland in the next few years. That may indicate that the present legal construction of the standardised funds is not suitable to Polish debt collection market and do not meet the needs of IFCs.

Up to date, only non-standardised funds have been established in Poland. Searching for the causes of this phenomenon in the questionnaire includes the appropriate question. In the survey conducted by the authors IFCs pointed out reasons of use of only non-standardised type of funds. The reasons were as follows (Krupa \& Buszko, 2015, pp. 379-387):

- the early stage of securitisation market development,

- the possibility of further issues of investment certificates in non-standardised securitisation investment fund type, 
- lower investments limits and higher elastic investment policy in non-standardised securitisation investment funds,

- lack of economic sense of standardised securitisation fund,

- lack of uniform-type receivables for standardised fund.

IFCs were asked about particular limitations emerging during the process of establishing securitisation funds. Only one of the IFCs pointed that it met barriers during creation of securitisation funds, i.e.: legal restrictions and a lack of investors purchasing certificates issued by the securitisation fund. Also, the authors asked IFCs question about particular limitations in the process of managing of investment funds. Five IFCs indicated that they have not found any limitations during management of securitisation funds. The other three IFCs listed limitations. They were as follows (Krupa \& Buszko 2015, pp. 379-387):

- legal restriction,

- low quality of securitised assets,

- low quality of cooperation with the participants of the process of securitisation,

- lack of appropriate human resources,

- high asset portfolio management costs.

\section{Conclusion}

Despite general low share of securitisation funds in the investment funds market and their short history in Poland, one may find that the growth of this segment of finance in Poland is fast, considering both the number of funds as well as their net assets value. The perspectives of further development of securitisation as well as securitisation investment funds can be assessed as advantageous. The main factors supporting this process are: cumulating of debts overdue, substantial increase of value of debts under management of debt collection services, the condition of low interest rates, implementing of taxation of assets of financial institutions in Poland (mainly banks) as well as maturing of mortgage loans. Searching by Polish investors for new and alternative investments should also support development of securitisation investment funds. Establishing and growth of new securitisation funds might be support by maturing of debt collection companies.

The good perspectives of development of securitisation in Poland was also pointed out by the managers of investment funds companies taking part in the survey prepared by the authors of the paper in 2015. The questioned managers positively evaluated future prospects of securitisation but they find it as of an average meaning for the IFCs in Poland. The special character of securitisation funds may explain such opinion, which is not a major point of interest of investment funds companies focusing mainly on traditional investment funds. The further development of securitisation investment funds will be dependent on number and severity of barriers and limitations. The most important can be classified in three major groups i.e. complexity of transaction, legal regulations and taxation. As complexity is a fundamental feature of securitisation, there are 
limited possibilities to diminish this type of barrier. The way of enhancing securitisation development in Poland is then through implementing propitious law and clear taxation rules. It should be noted that a significant impact on the development of the entire investment fund market in Poland, might have a new law dated September 5, 2016 on the amendment of the Income Tax Act of individuals and the Law on Income Tax from Legal Persons. The law will come into force at the beginning of 2017.

\section{References}

Liskowska, D. (2006). Fundusze sekurytyzacyjne jako forma refinansowania wierzytelności. In K. Gabryelczyk (Ed.), Nowe ustugi finansowe. Warszawa: CeDeWu.

IZFiA. (2016). Retreived 15.09.2016 from http://www.izfa.pl.

Directive 85/611/EEC of 20 December 1985 on the coordination of laws, regulations and administrative provisions relating to undertakings for collective investment in transferable securities (UCITS) (OJ L375).

Directive 2001/107/EC of the European Parliament and of the Council of 21 January 2002 amending Council Directive 85/611/EEC on the coordination of laws, regulations and administrative provisions relating to undertakings for collective investment in transferable securities (UCITS) with a view to regulating management companies and simplified prospectuses (OJ L41).

Directive 2001/108/EC of the European Parliament and of the Council of 21 January 2002 amending Council Directive 85/611/EEC on the coordination of laws, regulations and administrative provisions relating to undertakings for collective investment in transferable securities (UCITS), with regard to investments of UCITS (OJ L41).

Directive 2009/65/EC of the European Parliament and of the Council of 13 July 2009 on the coordination of laws, regulations and administrative provisions relating to undertakings for collective investment in transferable securities, UCITS IV Directive (OJ L302).

Directive 2011/61/EU of the European Parliament and of the Council of 8 June 2011 on Alternative Investment Fund Managers and amending Directives 2003/41/EC and 2009/65/EC and Regulations (EC) No 1060/2009 and (EU) No 1095/2010, AIFM Directive (OJ L174).

Directive 2014/91/EU of the European Parliament and of the Council of 23 July 2014 amending Directive 2009/65/EC on the coordination of laws, regulations and administrative provisions relating to undertakings for collective investment in transferable securities (UCITS) as regards depositary functions, remuneration policies and sanctions, UCITS V Directive (OJ L257).

Ustawa z dnia 27 maja 2004 r. o funduszach inwestycyjnych [Act of May 27, 2004 on investment funds and management of alternative investment funds] (Dz.U. 2004 nr 146 poz. 1546) (Poland). 
Ustawa z dnia 29 czerwca 1995 r. o obligacjach [Act of January 15, 2015 on bonds] (Dz.U. $1995 \mathrm{nr} 83$ poz. 420) (Poland).

Ustawa z dnia 29 sierpnia 1997 r. - Prawo bankowe [Banking Law of August 29, 1997] (Dz.U. 1997 nr 140 poz. 939) (Poland).

Ustawa z dnia 5 września $2016 \mathrm{r}$. o zmianie ustawy o podatku dochodowym od osób fizycznych oraz ustawy o podatku dochodowym od osób prawnych [Act of September 5, 2016 on amending the Law on Income Tax of Individuals and the Law on Income Tax of Legal Persons] (Dz.U. 2016 poz. 1550) (Poland).

Krupa, D. (2008). Zamknięte fundusze inwestycyjne. Warszawa: CeDeWu.

Krupa D., \& Buszko M. (2015). Securitisation Funds in Poland in Investment Fund Companies' Perspective. Procedia Economics and Finance, 30. doi:10.1016/S2212-5671(15)01305-2.

\section{Acknowledgements}

Author contributions: authors have given approval to the final version of the article. Authors contributed to this work as follows: D.K. and M.B. developed the concept and designed the study; D.K. and M.B. collected the data; D.K. and M.B. analysed and interpreted the data; D.K. and M.B. prepared draft of article; D.K. and M.B. revised the article critically for important intellectual content.

Note: some part of the results of the research in scope of management of securitisation funds was already presented (Krupa \& Buszko, 2015). 


\section{Appendix}

Table 1.

Structure of the IFCs in the survey research

\begin{tabular}{cccc}
\hline Specification & $\begin{array}{c}\text { IFCs which ever managed } \\
\text { securitisation fund }\end{array}$ & $\begin{array}{c}\text { IFCs which never did } \\
\text { manage securitisation fund }\end{array}$ & Total amount of IFCs \\
\hline $\begin{array}{c}\text { The number of question- } \\
\text { naires sent }\end{array}$ & 24 & 32 & 56 \\
$\begin{array}{c}\text { The number of returned } \\
\text { questionnaires }\end{array}$ & 8 & 6 & 14 \\
\hline
\end{tabular}

Source: own preparation.

Table 2.

The answer to the question: do you find any particular limitations and barriers in the process of development of securitisation in Poland?

\begin{tabular}{cccc}
\hline Specification & IFC without securitisation funds & IFC with securitisation funds & Sum \\
\hline Yes & 3 & 6 & 9 \\
No & 3 & 2 & 5 \\
Sum & 6 & 8 & 14 \\
\hline
\end{tabular}

$\mathrm{N}=14$.

Source: own preparation based on the authors' research.

Chart 1.

Structure of the investment funds market in Poland at the end of May2016 (in \% of NAV)

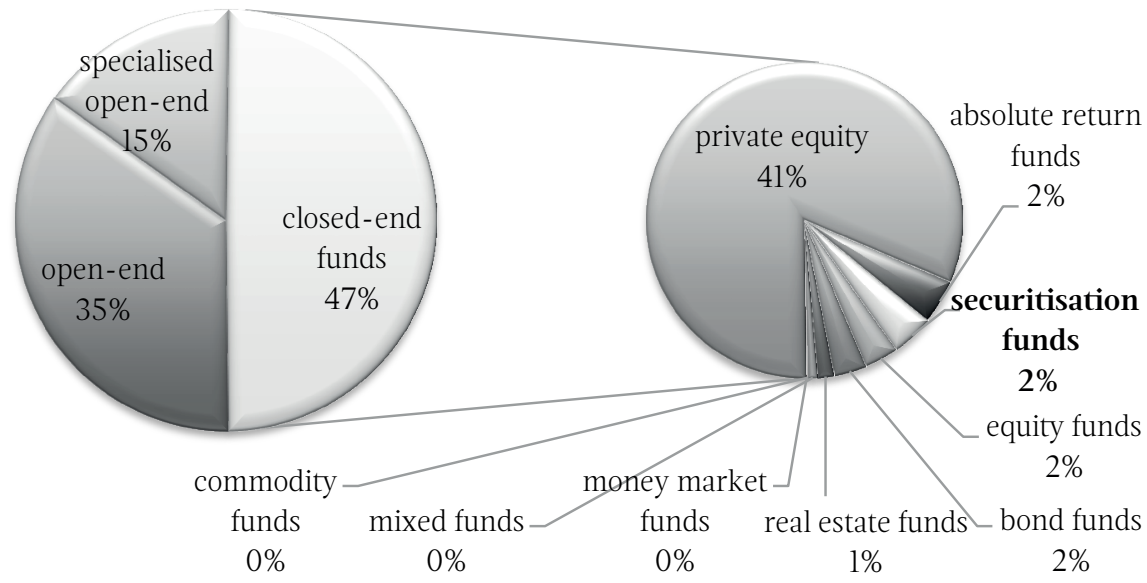

Source: own preparation based on data of IZFiA (2016). 


\section{Chart 2.}

Securitisation funds on the investment funds market in Poland at the end of May2016 (\% in \% of the total number of funds)

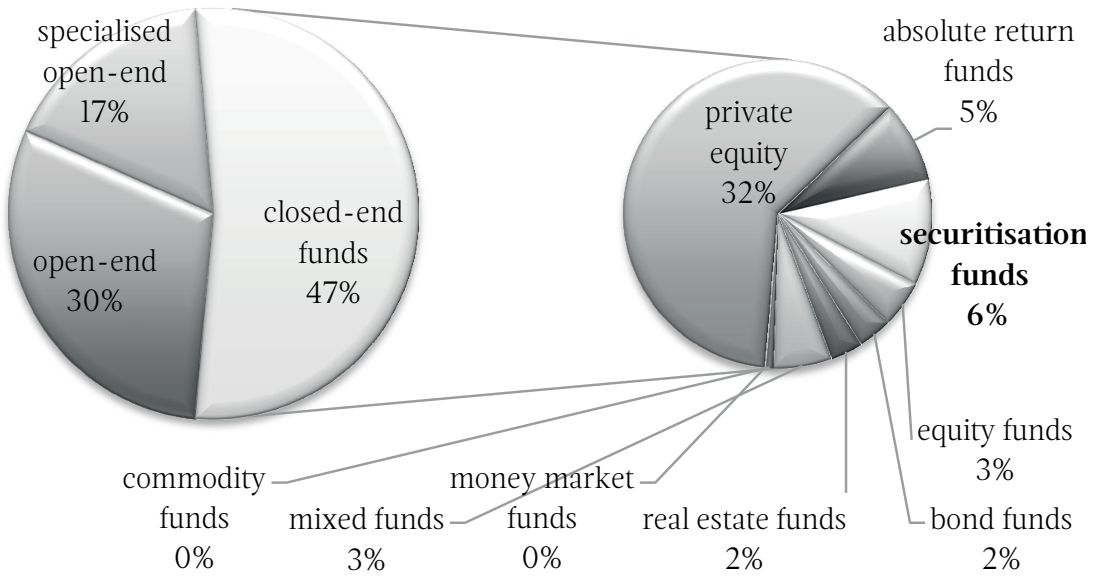

Source: own preparation based on data of IZFiA (2016).

\section{Chart 3.}

Securitisation funds market in Poland in the period 2005-2016* (NAV in milions PLN and number of funds)

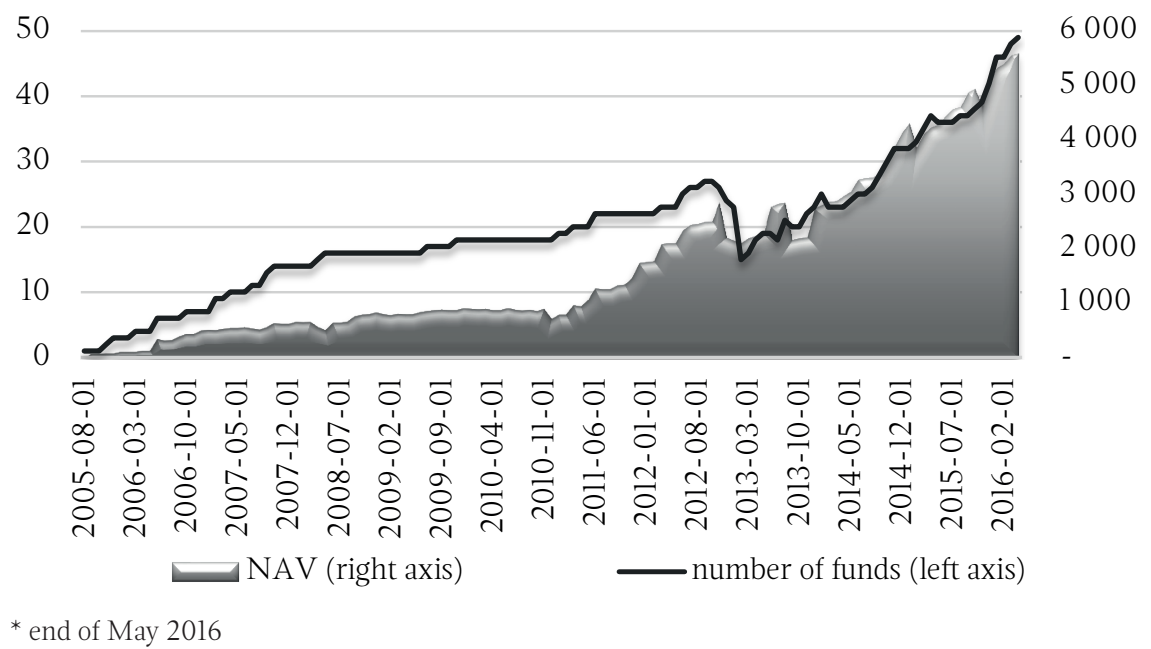

Source: own preparation based on data of IZFiA (2016). 


\section{Chart 4.}

Rank of investment fund companies according to NAV of securitisation funds in the period 2012-2016 (in million PLN)

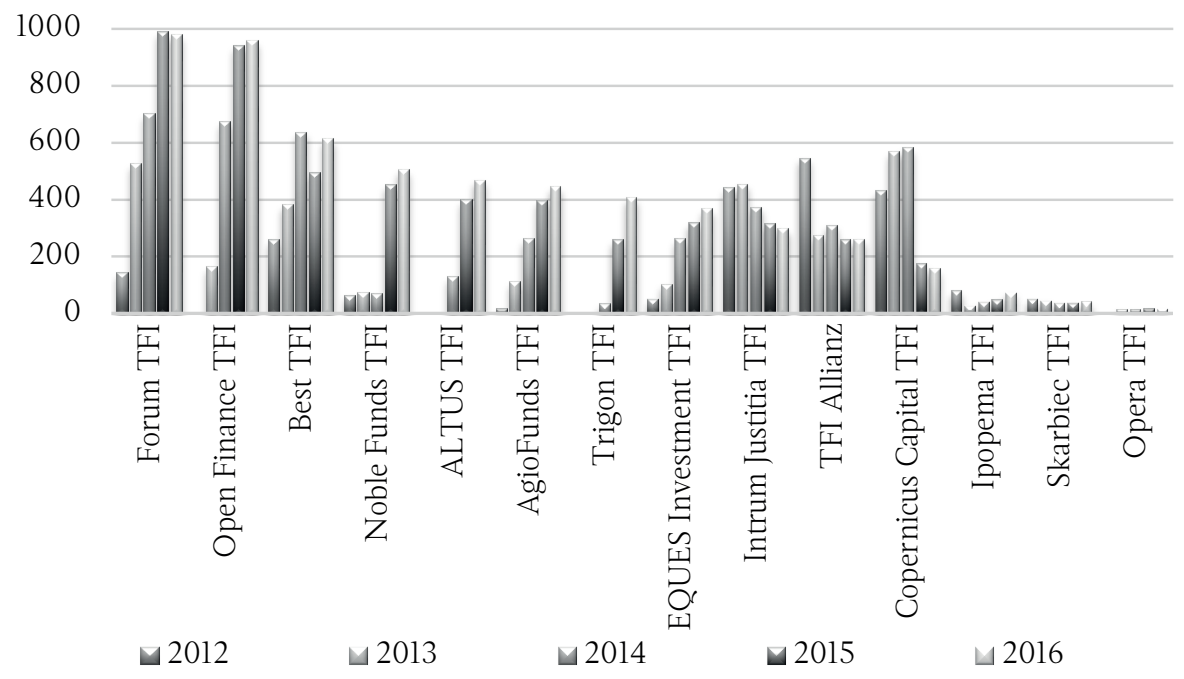

Source: own preparation based on data of IZFiA (2016).

\section{Chart 5.}

The answer to the question: how do you assess perspectives of development of assets securitisation in Poland in the next few years?

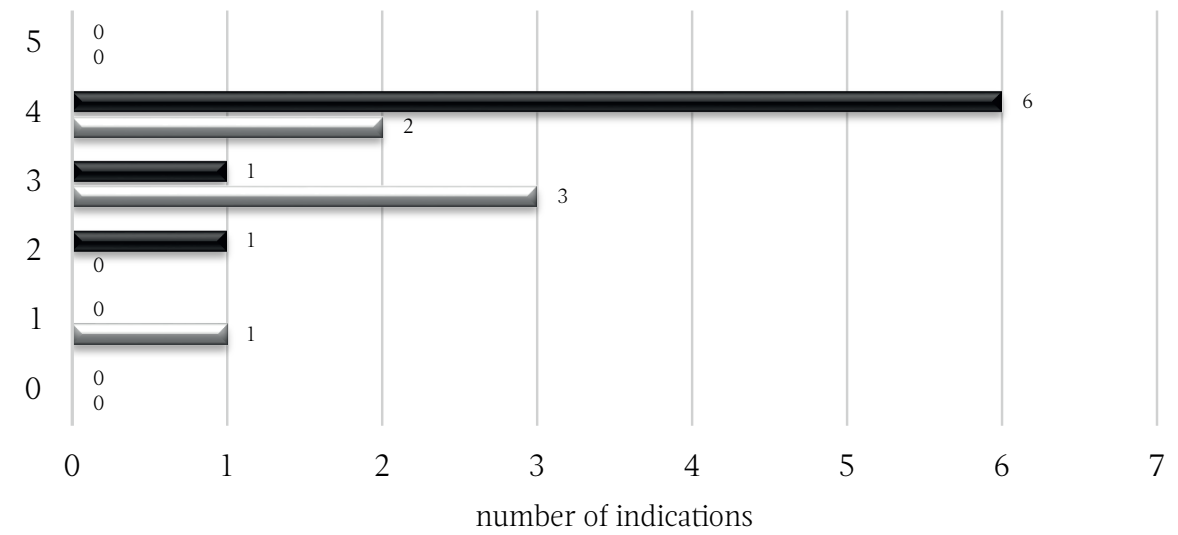

a IFC with securitisation funds, $N=8 \quad \square$ IFC without securitisation funds, $N=6$

5 - the best perspectives; 0 - the worst perspectives; $\mathrm{N}=14$; multiple choice.

Source: own preparation based on the authors' research. 


\section{Chart 6.}

The answer to the question: please indicate which limitations and barriers are hindering the most process of development of securitisation in Poland

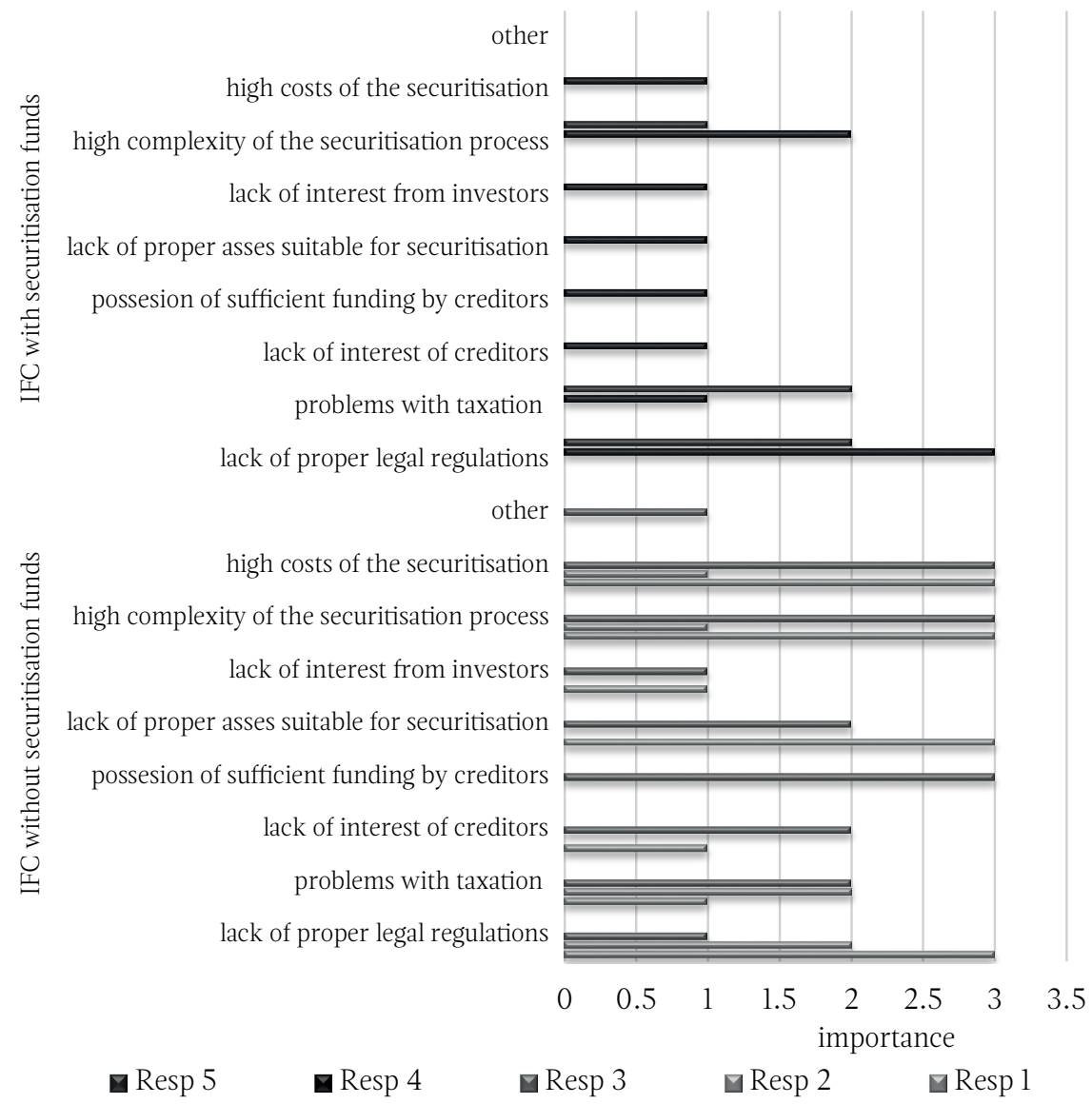

1 - low importance; 2 - average importance, 3 - strong importance; N=14.

Source: own preparation based on the authors' research. 


\section{Chart 7.}

The answer to the question: What are, in your opinion, perspectives of future participation of investment funds in securitisation of receivables in Poland?

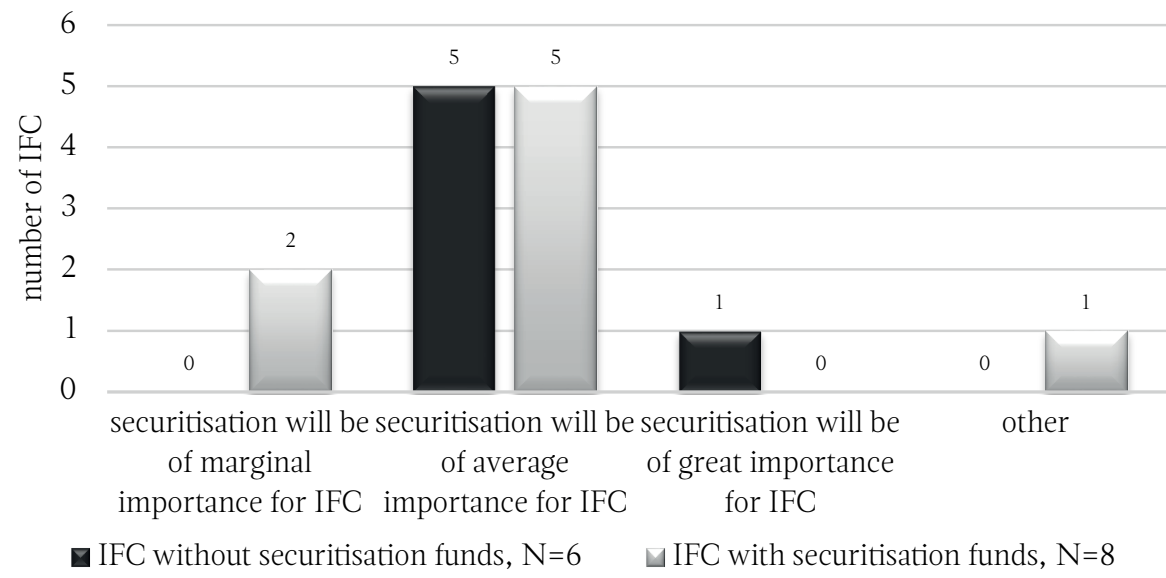

$\mathrm{N}=14$.

Source: own preparation based on the authors' research.

\section{Chart 8.}

The answer to the question: According to your opinion, what type of securitisation funds will be most commonly established in Poland in the next few years?

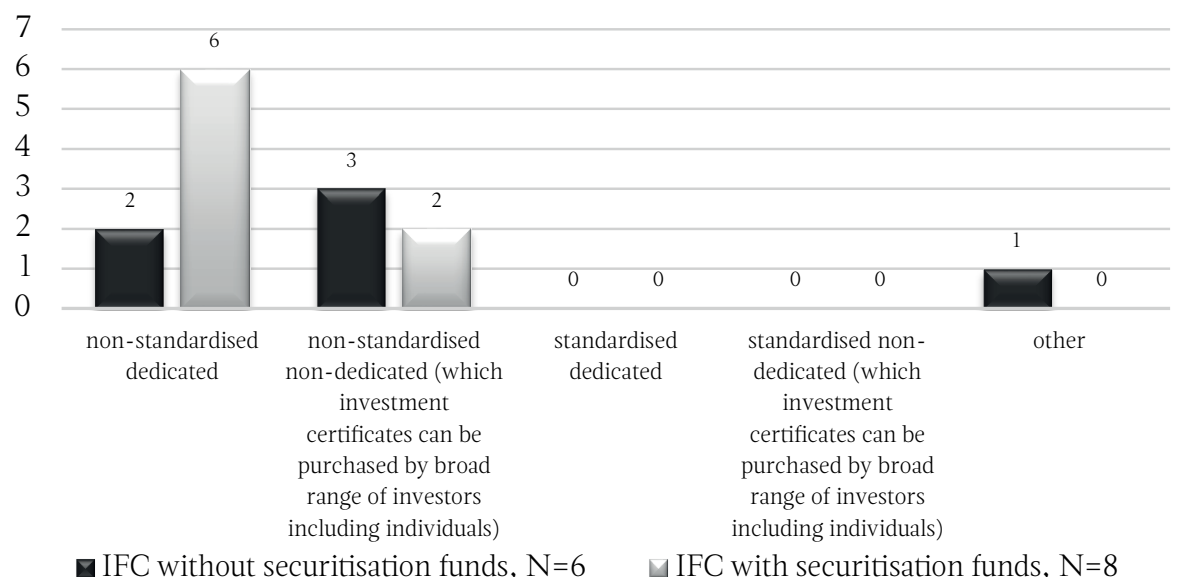

$\mathrm{N}=14$.

Source: own preparation based on the authors' research. 